\title{
Tighten your belt or lose your pants? Not if it is tailored to the patient-annuloplasty during remodeling
}

\author{
Charles M. Wojnarski, MD, MS, ${ }^{\mathrm{a}}$ and Eric E. Roselli, $\mathrm{MD}^{\mathrm{b}}$
}

\footnotetext{
From the ${ }^{\mathrm{a}}$ Department of Thoracic and Cardiovascular Surgery, University Hospitals Cleveland Medical Center, Cleveland, Ohio; and the ${ }^{\mathrm{b}}$ Department of Thoracic and Cardiovascular Surgery, Cleveland Clinic, Cleveland, Ohio.

Disclosures: Authors have nothing to disclose with regard to commercial support.

Received for publication Oct 31, 2017; accepted for publication Nov 11, 2017; available ahead of print Dec 14, 2017.

Address for reprints: Charles M. Wojnarski, MD, MS, University Hospitals Cleveland Medical Center, 11100 Euclid Ave, Cleveland, OH 44106 (E-mail: charles.wojnarski@uhhospitals.org). J Thorac Cardiovasc Surg 2018;155:895-6

$0022-5223 / \$ 36.00$

Copyright (c) 2017 by The American Association for Thoracic Surgery

https://doi.org/10.1016/j.jtcvs.2017.11.030
}

The aortic root is an astonishingly complex and evolutionarily sophisticated structure that serves intermittently opposing, yet complementary roles. In systole, it functions as a low-resistance conduit; in diastole, its cusps parachute to unload immense retrograde and radial forces gently, preventing ventricular reflux, and the resulting blood vortices feed the coronaries as the ventricle relaxes. ${ }^{1}$ The beauty of its form was first documented by da Vinci in $1513 .{ }^{2}$ Today, we are only beginning to understand its many functions since the development of a 4-dimensional magnetic resonance imaging-based "glass model," like the one envisioned by the inventor more than 500 years ago.

The first pragmatic and durable operation aimed at treating aortic root aneurysm was introduced by Bentall and De Bono in 1968 in the form of composite mechanical valve conduit replacement. In an effort to avoid lifelong anticoagulation in young patients with aortic root aneurysm and an otherwise anatomically normal aortic valve, Sarsam and Yacoub developed the aortic root remodeling technique in 1979, and later David and Feindel developed the aortic valve reimplantion technique in 1988. Among others, Lansac and Schäfers bridged the gap between the 2 procedures by adding external annuloplasty to the root remodeling procedure in an attempt to prevent long-term annular dilation. The development and refinement of these procedures is a remarkable testament to the innovative and reflective nature of cardiac surgeons. In the proper hands and applied to the right patient, all 3 methods have excellent short-term safety and midterm durability. ${ }^{4-6}$

The article in this issue of the Journal by Kunihara and colleagues $^{7}$ describes the perioperative and midterm outcomes of patients who underwent aortic root remodeling by a single surgeon from 1995 to 2013. Beginning in 2009, one of the authors (Hans-Joachim Schäfers) performed external suture annuloplasty in most cases. Before that year, no patient underwent annuloplasty. Kunihara and colleagues ${ }^{7}$ compare the approaches (root remodeling

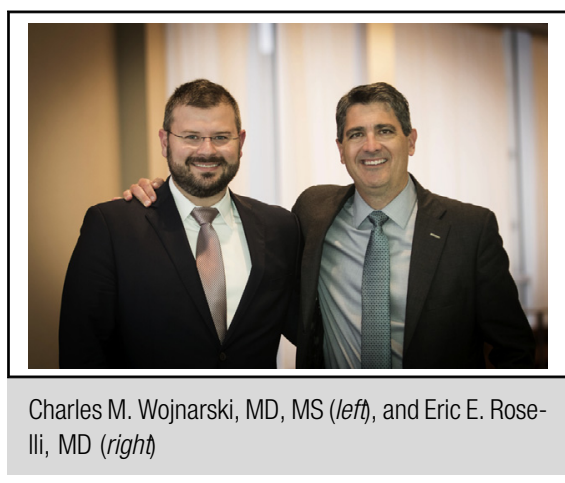

Central Message

In properly selected patients with aortic root aneurysm and lack of intrinsic aortopathy, root remodeling induces ventricular remodeling with or without the addition of external suture annuloplasty.

See Article page 885 .

with annuloplasty vs no annuloplasty) in terms of freedom from reoperation through 6 postoperative years and various echocardiographic measures at follow-up. Propensity score matching and linear mixed models were used to account for group differences at baseline and in follow-up.

There were no significant differences between groups with regard to reoperation through 6 years. Both aortoventricular junction diameter and left ventricular end-diastolic diameter were lower at discharge in the annuloplasty group. After 2 years, however, there was no difference between groups. This reverse annular and ventricular remodeling attributable to the aortic root remodeling procedure is the key finding of the study. It is the correction of aortic insufficiency that leads to this phenomenon. ${ }^{8}$ Annuloplasty allowed annular and ventricular remodeling to occur more quickly; however, this had no effect on early need for reoperation. In our view, ventricular remodeling after root stabilization may suggest that earlier intervention in these patients may portend a survival benefit.

The generalizability of this study is limited by sample selection bias, because the 2 groups come from different periods in the surgeon's experience. Although annuloplasty is the intervention studied, other minor variations in technique cannot be accounted for in the present analyses. Furthermore, institutional referral patterns and surgeon's criteria for operation have created a very specific population of patients, with more than $40 \%$ having bicuspid aortopathy 
and only $7 \%$ having Marfan syndrome. In patients with bicuspid aortopathy and root aneurysm seeking to avoid anticoagulation, root remodeling may have a role. For patients with annuloaortic ectasia and intrinsic aortic connective tissue disorders such as Marfan syndrome, however, we would advocate reimplantation-replacing all aortic root tissueto prevent future dilation of the aortoventricular complex. ${ }^{4-6}$

Our approach to selection of operation has always been an individualized one, taking into account each patient's underlying pathology, aneurysm phenotype, and type and degree of valvular dysfunction. ${ }^{9}$ Fundamental to this approach is a shared decision making with the patient regarding an operative plan that is based on his or her values, lifestyle, and expectations. Refinement of both reimplantation and remodeling procedures and study of associated outcomes are critical to maintaining this goal of personalized surgical care.

We applaud Kunihara and colleagues ${ }^{7}$ on their introspective approach to modifying aortic remodeling. It appears that annuloplasty does alter the size of the aortic annulus immediately at operation, but correction of aortic insufficiency by stabilizing the root with a remodeling procedure accomplishes this on its own in time.

\section{References}

1. Yacoub MH, Kilner PJ, Birks EJ, Misfeld M. The aortic outflow and root: a tale of dynamism and crosstalk. Ann Thorac Surg. 1999;68(3 Suppl):S37-43.

2. Robicsek F. Leonardo da Vinci and the sinuses of Valsalva. Ann Thorac Surg. 1991:52:328-35.

3. Markl M, Frydrychowicz A, Kozerke S, Hope M, Wieben O. 4D flow MRI. J Magn Reson Imaging. 2012;36:1015-36.

4. Leyh RG, Fischer S, Kallenbach K, Kofidis T, Pethig K, Harringer W, et al. High failure rate after valve-sparing aortic root replacement using the "remodeling technique" in acute type A aortic dissection. Circulation. 2002;106(12 Suppl 1):I229-33.

5. Bethea BT, Fitton TP, Alejo DE, Barreiro CJ, Cattaneo SM, Dietz HC, et al. Results of aortic valve-sparing operations: experience with remodeling and reimplantation procedures in 65 patients. Ann Thorac Surg. 2004;78:767-72; discussion 772 .

6. Hanke T, Charitos EI, Stierle U, Robinson D, Gorski A, Sievers HH, et al. Factors associated with the development of aortic valve regurgitation over time after two different techniques of valve-sparing aortic root surgery. J Thorac Cardiovasc Surg. 2009; 137:314-9.

7. Kunihara T, Arimura S, Sata F, Giebels C, Schneider U, Schäfers H-J. Aortic annulus does not dilate over time after aortic root remodeling with or without annuloplasty. J Thorac Cardiovasc Surg. 2018;155:885-94.e3.

8. Leshnower BG, Guyton RA, McPherson L, Kilgo PD, Chen EP. Improved left ventricular function and remodeling after the David V for significant aortic insufficiency. Ann Thorac Surg. 2013:96:2090-4.

9. Levack MM, Aftab M, Roselli EE, Johnston DR, Soltesz EG, Gillinov AM, et al. Outcomes of a less-invasive approach for proximal aortic operations. Ann Thorac Surg. 2017;103:533-40. 